\title{
Soviet scientist accused
}

A Soviet scientist, employed at the Arctic and Antarctic Institute of the State Hydrometeorological Commission, made use of research trips abroad to pass on classified information to United States intelligence, according to Pravda. Soviet newspapers are usually reticent about reporting criminal or espionage cases, but this particular story was considered worthy of a three-part serial. During the past two years, the Party agitprop literature has paid considerable attention to the risks faced by Soviet sailors and others obliged to travel to the capitalist world. The history of the scientist-spy, Yurii V. Pavlov, (code-name Rolf Daniel) was presumably given such extensive coverage to show that even a highly educated Soviet scientist is not immune to temptation.

Pavlov, according to his own statement, quoted in Pravda, was the son of a mining engineer and an English teacher. Born in 1935, he studied in Leningrad, specializing in experimental nuclear physics, but abandoned his dissertation work out of boredom. After being involved for some time in a "fantastic project" to create artificial diamonds using nuclear explosions, he drifted out to the Soviet Far East and then, in 1961, took part in an expedi-

\section{is good news}

tree species and age, to provide the basis of stratified sampling schemes.

No needle yellowing, such as that found in Norway spruce in West Germany, occurred in Britain. A strong regional effect for crown density and needle age could have been caused by local environmental factors or by bias among surveying teams. Scots pine and Norway spruce hold their needles for longer at higher altitudes but had less dense crowns where rainfall is higher. Scots pine held its needles for longer, but Sitka spruce had less dense crowns, in high sulphur deposition zones. None of these signs of sickness was caused by previously unknown phenomena.

Although the news is good for Britain's trees, optimism should only be cautious. A single survey has limited use in detecting changes in forest health, but patterns should emerge with subsequent resurveys. West German surveys cannot easily be compared with the UK data because of differences in management, altitude, climate and, particularly, age of trees (old trees are more susceptible to pollution damage). As the trees in the UK survey grow older and the local levels of pollution vary with time, patterns of damage, if they exist, will emerge.

Maxine Clarke

*Forestry Commission Research and Development Paper 142 Forest Health and Air Pollution: 1984 Survey $£ 1.40$ tion to Japan, Tahiti, Fiji and Hawaii aboard the doyen of Soviet research vessels, Vityaz. Here, Pravda implied, Pavlov proved a misfit, being temperamentally unsuited to carry out serious scientific work without "fanfares or laurels"

He returned to Leningrad and for the next seven years he apparently drifted from job to job seeking good pay rather than interesting work.

For a time, he was employed in what was entered in his official work record book as "secret work and documents". In 1969, he went to work for the Marine Register of the USSR and, in his own words, became "one of the central figures in the atomic inspection of the register". Between 1977 and 1980 he travelled abroad to meetings of an international working party on safety regulations for nuclear ships, visiting London (four times), Genoa, Ottawa and Hamburg. Finally he left this job however, feeling that it was "too narrow" for him and in the autumn of 1981 began working at the Arctic and Antarctic Institute, in order that he might avail himself of the opportunity of foreign travel aboard the research ship Professor Vize.

During his travels, Pavlov stated, he was recruited by West German intelligence and the Central Intelligence Agency. The Pravda narrative traces out the course of his contacts in foreign ports, the "spy kit" issued to him, the efforts of Soviet counter-intelligence to track him down and his final confession and repentance and the imposition of an (unspecified) appropriately severe sentence" (presumably the death penalty) by a military court.

The exact data which Pavlov allegedly handed over to the West are left vague, but a tailpiece entitled "instead of an epilogue" puts the story firmly in the context of US/NATO "aggression" as revealed by "star wars", psychological warfare and disinformation.

Ceaseless vigilance, says Pravda, is the "principal weapon" in this ideological war. Pavlov, on the contrary, exhibited the "lightmindedness" of "ideologically unstable people", who "live in a vacuum" and who must be excised from Soviet society as a "foreign body".

Perhaps the most telling summing-up of Pavlov's character faults, however, comes not in this tailpiece but in the body of the narration, where he is accused of "Manilovism". This word, drawn from the name of a character in Gogol's Dead Souls, does, indeed, typify the shiftlessness and lack of stability which, presumably, Pavlov exhibited, but it is a word that has not recently been much in vogue in Soviet character-analysis, having been one of Stalin's favourite epithets of condemnation.
Nuclear waste

\section{EPA regulates at last}

\section{Washington}

THE US Environmental Protection Agency (EPA) has at last issued regulations that it wants to see enforced at high-level radioactive waste disposal sites. But the "final" standards are unlikely to be the end of a long inter-agency dispute on how the regulations will be enforced, and there seem likely to be many opportunities yet for opponents of geological disposal to mount legal challenges.

EPA has come out on the wrong side of an argument with the Nuclear Regulatory Commission (NRC) over regulation of disposal sites, the upshot of which is that EPA can only implore NRC to comply with a list of assurance requirements designed to ensure that there will be no significant leakage of radioactivity for 10,000 years after disposal operations are completed. The practices at the disposal sites while they are still in operation will be regulated by NRC, whose standards are different from those promulgated by EPA.

The need for a permanent resting place for US nuclear waste has become urgent in recent years. In 1982, a report from the Congress's Office of Technology Assessment warned that some power stations might have to close down unless provision was made for disposing of high-level waste, mostly used fuel rods, now accumulating in ponds at power station sites. Given the tarnished public image that nuclear power already suffers in the United States, that was an option to be avoided at all costs.

Responsibility for selecting and operating a disposal site rests with the Department of Energy, which is now engaged in processing some 20,000 comments on its proposal to carry out on-site investigations at three possible sites for a high-level waste repository. By the end of the year, the department hopes to have confirmed its previous choices and to have issued final environmental assessments. A final decision will then be made by the President and Congress.

The standards that EPA has now issued limit exposures to members of the public to 25 millirems to the whole body, 75 millirems to the thyroid and 25 millirems to any other organ. There is also a waiver whereby the EPA administrator can raise the 25 millirems limit to 100 millirems if he sees fit or 500 millirems for a one-off dose. And the standards limit projected releases of radioactivity to the environment for 10,000 years; EPA estimates that compliance with the containment requirements means that there will be no more than 1,000 cancer deaths over the entire 10,000 years considered. Tim Beardsley 